\title{
SZABÓ Katalin
}

\section{INTÉZMÉNYI VÁLLALKOZÁSOK: INTÉZMÉNYI ÚJÍTÁSOK - LÉTEZŐ INTÉZMÉNYEK KOMBINÁCIÓJÁVAL}

\begin{abstract}
Az intézményi változások utóbbi két-három évtizedben tapasztalható dinamikája, eddig nem ismert intézmények felbukkanása, ráirányította figyelmet a kérdésre, hogy miként jönnek létre új intézmények. A 90-es évektốl kezdve a szakirodalomban megjelent egy új terminus technicus: az intézményi vállalkozás (institutional entrepreneurship), amelyet az egyének és szervezetek új intézmények létrehozására, a meglévő́k kardinális átalakítására vagy lerombolására irányuló céltudatos akciójaként definiálnak. A szerzó az intézményi vállalkozások lényegét a korábban ismert intézmények új kombinációinak kialakításaként ragadja meg. A tanulmány a sharing economy példáján - az Uber és az Airbnb eseteit használva - mutatja be az intézményi vállalkozások múködését a gyakorlatban, több paraméter szerint szembeállítva őket a konvencionális piaci intézményekkel. Az írás kitér az intézményi vállalkozások széles körú, gyakran globális léptékú extern hatásaira is. ${ }^{1}$
\end{abstract}

\section{Kulcsszavak: intézményi változások, változásmenedzsment, intézményi vállalkozások, sharing economy}

Az intézményi közgazdaságtan sokáig fóként a stabil intézményi keretek elemzésére és e keretekhez való alkalmazkodás vizsgálatára koncentrált. A gazdasági aktorokat az intézményi hálóba beágyazottként mutatta be, olyan szereplőkként, akik adottságnak tekintik e kereteket, és alkalmazkodnak hozzájuk. Még az intézményi közgazdaságtan azon képviselói is, akik az intézményi változásokra koncentráltak, árnyékban hagyták az aktorok szerepét az új intézmények létrehozásában, és az intézmények keletkezését, átalakulását exogén tényezőknek, a technológiai fejlódésnek vagy az evolúciós erók játékának tulajdonították (Williamson,1975, 1985; Hayek, 1988; North, 1990; Nelson, 2005.) Az utóbbi két-három évtizedben azonban a kutatók, elsősorban a vállalatelmélettel és a szervezetelmélettel foglalkozók, az érem másik oldaláról is elkezdték vizsgálni az intézményeket (DiMaggio, 1988; Dorado, 2005; Battilana - D'Aunno, 2009; Lawerence et al., 2009). Abból indultak ki, hogy a fennálló intézmények ugyan valóban behatárolják a szereplők mozgásterét, de a szereplók is hatnak az intézményekre, sót meghatározó szerepük lehet az új intézmények létrehozásában. Az intézmények emberi konstrukciók, nem valamiféle, a szereplók felett álló, megváltoztathatatlan adottságok. A 90-es évektől ezért hangsúlyt kapott a kérdés: Miként jönnek létre új intézmények? Milyen mozgatóerők hajtják előre az intézményi változásokat? Hogyan múködnek az új intézmények létrehozására irányuló intézményi vállalkozások a gyakorlatban, és milyen externális hatásokat fejtenek ki a gazdasági-társadalmi környezetükre? Ezzel együtt járt a szereplók passzivitásának a feloldása az elemzésekben, azaz a változás generálóinak a középpontba állitása, az institutional entrepreneurship terminus technicus bevezetésével. A szereplők passzivitását feloldó megközelítés Agency elmélet ${ }^{2}$ néven ${ }^{3}$ vonult be a szakirodalomba a múlt század 80 -as éveinek a végén (Di Maggio,1988).

Az intézményi vállalkozás definíciója és a probléma relevanciája

Az agency elméletek középpontjában a vállalkozók és a vállalkozás egy különös típusa áll: az intézményi vállalkozás. Az intézményi vállalkozást, amely a szereplókhöz köthető „az egyének és a szervezetek céltudatos akciójaként” definiálják, „,amely akció intézmények létrehozását, javitását és a lerombolását célozza” (Lawrence - Suddaby, 2006, p. 215.). A szakirodalomban meghonosodott definíciókhoz képest azonban szükségesnek tartjuk néhány fontos elemmel gazdagítani az intézményi vállalkozás értelmezését (a kiegészítéseinket dőlt betúkkel jelezzük.) 


\section{A definíció kiterjesztése}

Kiterjesztett definíciónk szerint az intézményi vállalkozás a piaci és az állami szervezetekben (vagy azokon kiviuil) múködő egyének és csoportok céltudatos akciójaként ragadható meg, amely új intézmények létrehozását, a meglévők kardinális átalakítását vagy lerombolását, vagyis a radikális intézményi újitásokat célozza. Bockhaven és munkatársai nyomán a definíció fontos kiegészítésének tartjuk, hogy „,az intézményi vállalkozás teljes területeket céloz meg, átfogó hálózatokat, kulturális-kognitív rendszereket, szervezeti archetípusokat és a szervezetek kollektív akcióinak repertoárját" (Bockhaven et al., 2015, p. 175.). ${ }^{4}$ Más szavakkal az intézményi vállalkozás nem lokalizált, hanem nagy léptékü (Raffaely - Glynn, 2015, p. 409.). Az intézményi vállalkozók, akiknek a tevékenysége meghatározó a jelentős társadalmi-gazdasági következményekkel járó új intézmények kialakításában, sokféle új intézménytípust indítanak útjára. 30-40 évvel ezelőtt senki sem hallott még e-piacokról, crowdsourcingról, Facebookról vagy sharing economyról. Ezeket az új, és az életünket átformáló intézményeket kreatív személyiségek, intézményi vállalkozók kezdeményezték, és vitték sikerre, akik Pierre Omidyartól Mark Zuckerbergig arccal és névvel azonosíthatók.

$\mathrm{Az}$ elektronikus bolhapiacok elófutára az 1995ben alapított e-Bay volt. Magyar megfelelóje a 2000től múködő Vatera is sikeres, de még a kevésbé fejlett országokban is megtalálhatjuk az e-Bay helyi változatát. (Ilyen például a készmúves termékeket forgalmazó Ethiopian Artisan nevú e-piac.) Az ún. Job boardok, az új típusú e-munkaközvetítók vagy az ár-összehasonlító oldalak is megtalálhatók mindenütt: a Facebookon múködő közösségi munkaközvetítőktől, a szállásközvetító Trivagón keresztül a VietnamWorksig. A globalizáció intézményi jelleget is ölt, az új intézmények szétterjedése azonban együtt jár a sajátos helyi változatok megjelenésével.

Természetesen a régebbi korokban is jöttek létre új intézmények. Az iskolapélda az 1602-ben alapított Holland Kelet-indiai Társaság, amely egyben a kapitalizmus máig meghatározó intézményének, $a$ tôzsdének a születését is jelentette. A XVII. század elején azonban nem beszéltek intézményi vállalkozókról vagy intézményi vállalkozásokról. Ugyanez áll olyan nagy horderejú kezdeményezésekre, mint az 1960-as, 70-es évek konglomerátumai. Mind a részvénytársaság és a tőzsde létrehozóira, mind a konglomerátum-alapítókra ráillik azonban a fentebb adott definíció, ezért ők, megítélésünk szerint, intézményi vállalkozóknak tekinthetók.

Mint ismeretes, az 1960-as 70-es évek Amerikájában a piac újdonsült szereplői a sok, kisméretú, viszonylag kis piaci részesedéssel bíró, egymástól me- rốben eltérô profilú vállalatot óriási társaságokká szervezték. Ez egyben egy addig ismeretlen intézmény, a konglomerátum életre hívását jelentette. Mire az egyegy iparágat egyedül vagy néhány más céggel együtt uraló óriáskonszernek észbe kaptak, addigra már nagy gazdasági hatalommal bíró, veszélyes, ,vegyes profilư” versenytársaik születtek, olyasfélék, mint az ITT, a Litton Industries vagy a Textron.

A konglomerátumalapítókat Paul Samuelson annakidején expanziókereskedőknek nevezte, mert az outsiderek konglomerátumaik gyors növekedését hitelből finanszírozták. A hiteleket azután részvényeik - a gyors növekedésnek köszönhető - árfolyamnyereségéből fizették vissza. Az értékpapírpiac árfolyamnövekedéssel jutalmazta látványos terjeszkedésüket. „Harmincéves, gátlás nélküli, szinte gyermek üzletemberek majdhogynem egyetlen éjszaka alatt a dollár ezrek piramisait tízmilliókká szaporítják" - írta róluk Samuelson a Közgazdaságtan címú alapmúvében (Samuelson, 1976, p. 669.).

Ezzel az eredeti intézményi vállalkozással tudtak a pénztelen kívülállók, az „,újonnan érkezett, önerőből feltört fickók, akik nem tartoztak a Yale-i koponyákhoz" (Samuelson, 1976, p. 670.), versenyre kelni a nagyhatalmú monopólumokkal és oligopóliumokkal, megtörve a megmerevedett piaci és tulajdoni struktúrákat. A konglomerátumalapítók nem illeszkedtek be a fennálló intézményi rendbe, hanem - új intézmény megalkotásával - mintegy kikerülték azt. Bár a 60-as 70-es években született konglomerátumok közül több tönkrement vagy felvásárolták, és a konglomerációs hullám is lecsengett, mégis maradandó hatással volt az ipari struktúrára és a vállalatfelfogásra. Ma a konglomerátum a vertikálisan vagy horizontálisan szervezett vállalatcsoportokkal egyenrangú képződmény.

Az említettekhez hasonló intézményi vállalkozások a XVIII. században, de még a XX. század második harmadában sem voltak túl gyakoriak. Ma azonban tömegesen jelennek meg új intézmények és szélsebesen terjednek szét a glóbuszon. Ezért vált frekventált kutatási iránnyá az intézményi vállalkozások elemzése. Mind a részvénytársaságokat, mind a konglomerátumokat létrehozó intézményi vállalkozások szervezeti újitásokat vezettek be, mégsem azonosíthatjuk az intézményi vállalkozásokat a szervezeti újításokkal. Az intézményi vállalkozás átfogóbb jelenség. Az elóbbi definíció értelmében csak azt tekintjük intézményi vállalkozásnak, amely „teljes területeket céloz meg, átfogó hálózatokat, kulturális-kognitív rendszereket, szervezeti archetípusokat és a szervezetek kollektív akcióinak repertoárját." Ez a meghatározás ráillik például a Holland Kelet-indiai Társaságra vagy a Facebookra, de nem vonatkoztatható olyan egyszerúbb szervezeti újításokra, mint a teammunka vagy a minőségi körök. 


\section{Az intézményi vállalkozások jellemzóii}

Bár a fenti példák is arra utalnak, hogy az intézményi vállalkozások fogalma egymástól nagyon különböző jelenségeket takarhat, van azonban e vállalkozásoknak néhány közös vonásuk, amely többé-kevésbé valamenynyi, e címszó alá sorolható jelenségre jellemző. Akárcsak az - általában vett - schumpeteri vállalkozásnak, az intézményi vállalkozásnak is a magja, célja, értelme az újitás. Nemcsak a technológiai újításokra, hanem az intézményi újításokra is alkalmazható a schumpeteri definíció: Az intézményi vállalkozások az új intézmények bevezetésével a termelési tényezók erôforrások) használatának új kombinációit hozzák magukkal (Schumpeter, 1911/1980). Megváltoztatják a termelési függ vények alakját ${ }^{5}$ az iparágban/területen (Schumpeter, 1939).

Az intézményi vállalkozások gyakran technológiai újitásokkal fonódnak össze. Nem ritka az az eset, amikor a meglévő intézményi keretek akadályozzák a technikai fejlódést, és azok, akik érdekeltek az új technológiák sikerében, csak az intézményi keretek széttörésével vagy megkerülésével vihetik sikerre a technológiaváltozást.

Az intézményi vállalkozások kilépnek a korábban áthághatatlannak tűnő tér- és időkorlátok közül, olyan területekre hatolhatnak be, amelyekre a korábbi intézményi keretek között nem volt lehetőség. A részvénytársaságok archetípusa a Holland Kelet-indiai Társaság például az önmagukban jelentéktelen tôkék egyesítésével Ázsia meghódításának és a távolsági kereskedelem fellendítésének - az egyéni tőkék lehetőségein messze túlmutató - programját valósította meg. Az intézményi vállalkozások jelen idejú változatai, a közösségi média vagy az elektronikus piacok még hatékonyabban rombolják le a térbeli távolságokból adódó korlátokat, és egyetemes, globális érintkezést, illetve tranzakciókat tesznek lehetóvé, kilépve nemcsak a város, hanem az ország vagy a kontinens határai közül is. Hasonlóképpen gyakran az idődimenziót is átrendezik ezek a vállalkozások. James Gleick sokat mondó könyvcímmel érzékelteti a gazdasági folyamatok idődimenzióinak átalakulását. Széles körben és gyakran idézett könyvének címe: Gyorsabban! (Gleick, 1999). A gyorsítás, amely nagy részben az intézményi vállalkozásokhoz kapcsolható, a gazdaság valamennyi szegmensére egyaránt érvényes, legyen szó a termelési ciklusról, a beruházási folyamatokról vagy éppen a tranzakciók lebonyolításáról. Legfeljebb a részvénytársaságokhoz és a tőzsdéhez kapcsolódó gyorsulás mértékében tér el a közösségi médiához és más - IT-re alapozott - intézményi vállalkozásokhoz köthető gyorsulástól.

Hasonló állítást fogalmazhatunk meg a termelési és a tranzakciós költségek csökkenésével kapcsolatban (Dew, 2013). Az intézményi változásoknál többnyire megjelenik ez a mozzanat, sôt gyakran ez a fó ütôkártya a régi intézmények kiszorításában. Az intézményi vállalkozások - ezt láthattuk például a konglomerátumok esetében - harcba szállnak a régi, megcsontosodott, megmerevedett monopolista struktúrákkal, és vagy kikerülik, vagy kiszorítják óket (Levy - Scully, 2007). Általában rugalmasabbak az inkumbenseknél, és jobban alkalmazkodnak a változó szükségletekhez. Nem függetlenül az elóbbiektől, az intézményi vállalkozások gyakran diszruptív jellegúek (Christiansen, 2013), nyomásukra felgyorsul az elavult intézmények kiszorítása a gazdaságból, ezáltal is növekszik a gazdasági folyamatok hatékonysága.

Az általában vett vállalkozáshoz hasonlóan, az intézményi vállalkozás is jelentős externális hatásokat vált ki, csak míg az első esetben e hatások az új technológiák, termékek vagy piacok révén bontakoznak ki, addig az intézményi vállalkozások az általuk kialakított új intézményekkel fejtik ki hatásukat. Az extern hatások körébe nem csupán a szúken vett gazdasági hatások tartoznak bele, hanem kulturális - a gondolkodásmódot és cselekvési mintákat érintó - hatások is. Az intézményi vállalkozások lényegéhez tartozik az is, hogy az externális hatások nem korlátozódnak az iparágra vagy egy adott országra, hanem gyakran globálisan érvényesülnek. E vállalkozások lehetőséget nyújtanak a környezetük, illetve a társadalom számára, hogy - az intézményi keretek kinyílásának köszönhetóen - korábban kihasználatlan, vagy kevéssé kihasznált forrásokat mozgósítsanak. A Holland Kelet-indiai Társaság például, megnyitotta az utat a kis, önmagukban életképtelen vagy kis potenciállal rendelkező tôketulajdonosok előtt, hogy olyan gigaprojekteket finanszírozzanak, mint Ázsia meghódítása vagy a távolsági kereskedelem kiépítése, amelyek azután tetemes hasznot hoztak számukra. A Holland Kelet-indiai Társaság intézményi vállalkozása nyomán elterjedt részvénytársaságok a technológia fejlődésének is lökést adtak, hiszen hogyan lett volna elképzelhetô elkülönült, kis magántőkék révén a közlekedés technológiai forradalmasítása, a vasutak kiépítése.

Ezzel párhuzamosan az említett intézményi változások megváltoztatták a tulajdonhoz való viszonyt is. Mind a konglomerátumok, mind a társaságok esetében merőben más a tulajdonos és a tulajdon kapcsolata, mint volt korábban. Mint tudjuk, a részvényesek gyakran elveszítik a tulajdonuk feletti ellenőrzést, míg a konglomerátumépítők olyan tulajdon felett is ellenőrzést szereznek, amelyhez nincs közük. A konglomerátumok intézményének a létrejöttével kiderült az is, hogy a vállalatbirodalmak kiépítéséhez nincs is feltétlenül szükség saját tőketulajdonra.

Az intézményi vállalkozások olyan tranzakciókat, technológiákat és termékeket tesznek elérhetővé, ame- 
lyek a korábbi intézményi keretek között elképzelhetetlenek voltak. Ezáltal növelik a gazdasági teljesítményt és a jólétet (Acs, 2006). Gondoljunk csak bele, hogy részvénytársaságok nélkül miként jöhettek volna létre a vasutak, amelyek az átlagemberek számára is megnyitották az utazás lehetőségét, és ezáltal egyértelmúen jólétnövelő hatással bírtak.

\section{A probléma relevanciája}

Nem véletlen, hogy az intézményi vállalkozás, illetve az intézményi vállalkozók az utóbbi egy-két évtizedben kerültek a figyelem középpontjába. A tudásalapú gazdaságban ugyanis a konformitással, a fennálló keretek passzív elfogadásával szemben általában is felértékelódik a cselekvés és annak alanya mind a gyakorlatban, mind az elméleti kutatásokban. ${ }^{6}$ Az intézményi vállalkozókra irányuló kutatások fontosságát nem kell külön igazolni egy olyan történelmi korszakban, amikor valóságos intézményi robbanásnak vagyunk tanúi. Szinte naponta nőnek ki a földből új intézmények - öszszefonódva az ICT-forradalommal, vagy a manapság gyakran emlegetett harmadik ipari forradalommal. „Elméletileg megfogalmazhatjuk, hogy az egyik történelemi korszakból a következóbe való átmenetnek ezek az idôszakai azok az idők, amikor az intézmények stabilitása és önazonossága (izomorfizmus) valamelyest gyengül, és az intézményi innovációk nagyobb szerepet játszhatnak" (Raffaely - Glynn, 2015, p. 411. kiemelés tőlem: Sz. K.). Az ipari társadalomról a tudásalapú társadalomra való átmenet korszakában szükségszerúen meggyengül a fennálló, „,bejáratott” intézmények stabilitása, és felértékelődnek az intézményi kereteket széttörő vagy átrajzoló intézményi vállalkozások.

A gazdaságban tevékenykedôknek nemcsak számos új intézménnyel kell megbarátkozniuk, teljesen általános az intézményi proliferáció jelensége is: az új intézmények gyors átterjedése más szektorokra, területekre, országokba. Példával szolgálhatnak erre a ma már szinte minden országban fellehetô e-piacok. Az intézményi vállalkozások az előbbi pontban részletezett általános jellemzői már önmagukban is elegendő indoknak tekinthetők a jelenség behatóbb vizsgálatára, a problémakör azonban Magyarországon azért is különösen aktuális, mert napjainkban országunk teljes intézményi átépitése zajlik, számos új intézmény kialakításával. Másutt is tapasztalhatók azonban radikális intézményi átépítések. (Elég, ha itt csak az Európai Unióban vagy az Egyesült Államokban napjainkban zajló változásokra utalunk, és a vele minden bizonnyal együtt járó, mélyreható intézményi átrendeződésre.) Mindez elég indok lehet arra, hogy megvizsgáljuk az intézményi vállalkozások, illetve vállalkozók mibenlétét, a megosztáson alapuló gazdasághoz sorolható példákon keresztül.

\section{A tanulmány célja, módszere}

A tanulmány célja, hogy az intézményi vállalkozásokat egy - a szakirodalomban nem szokványos - metszetben mutassa be, nevezetesen mint a meglévó intézmények és elemek újszerú összekapcsolásait, azaz új kombinációit. Fontosnak tartjuk azonban, hogy ne csak általában elemezzük az intézményi vállalkozást, hanem illusztrációként egy konkrét, manapság az érdeklődés középpontjában álló intézményi vállalkozáson: a megosztáson alapuló gazdaság esetein keresztül. Úgy véljük ugyanis, hogy két gyorsan terjeszkedő, megosztásos intézményi vállalkozást (az Ubert és az Airbnb-t) elemezve, plasztikusabban mutathatjuk be a vállalkozások e típusát, mint azt pusztán elméleti fejtegetésekkel tehetnénk. Bár az intézményi vállalkozásokban a kulcsszerep az innovatív személyiségeké, hiszen e kutatási irány legfontosabb megkülönböztető jegye éppen a szereplők passzivitásának a feloldása, intézményeket generáló tevékenységük kiemelése, azonban dolgozatunkban csak néhány utalás történik rájuk. Ennek magyarázata az, hogy az intézményi vállalkozás elemzése a közgazdász számára testhez állóbb feladat, ezért szükségképpen kisebb hangsúlyt kapnak a cselekvők (ágensek), illetve a dinamikára és a vállalkozók által előre hajtott átalakulás folyamatára vonatkozó elemzések. Erre alkalmasabbnak tûnnek az intézményi szociológia vagy más társadalomtudományi ágak képviselői. Ezért itt csak utalunk e fontos megközelítésekre, amelyekról jó öszszefoglalást ad Hardy és Maguire (2008).

Ami a módszereket illeti, a tanulmány kvalitatív módszerek alkalmazására épül. Mivel manapság még nincsenek kiterjedt és megbízható adatbázisok ${ }^{7}$, amelyek statisztikailag is megragadhatóvá tennék a cikkben tárgyalt jelenségeket, más módszer, mint a kvalitatív elemzés nem is igen jöhet számításba. A kvalitatív módszer általában akkor használatos, ha olyan új jelenségról vagy az ismert jelenségek újabb megközelítéséról van szó, amelyek esetében az új tudás generáláshoz még feltáró kutatásokra van szükség. A kvalitatív kutatások célja nem valamely többé-kevésbé kikristályosodott hipotézis tesztelése, hanem a jelenség lényegének a feltárása és megértése. Cikkünk célja éppen ez. A megosztáson alapuló gazdaság esetei, amelyeket az intézményi vállalkozás iskolapéldájaként tárgyalunk, feltétlenül új jelenségnek tekinthetôk, még ha természetesen voltak is előzményeik. A fogalmak pontosabb definiálása új, a szakirodalomban nem vagy kevéssé tárgyalt összefüggések bemutatása, megítélésünk szerint, hozzájárulhat az elméleti fejlődéshez.

A dolgozatban alkalmazott módszer másik rétege az összehasonlítás. A sharing economyt az alternatív piaci megoldásokkal állítjuk szembe, mivel úgy véljük, így jobban kidomborodhatnak a megosztáson alapuló 
intézményi vállalkozások sajátos tulajdonságai, és egyben megkülönböztető jegyei az alternatív, konvencionális piaci megoldásokhoz ${ }^{8}$ képest.

A megosztáson alapuló gazdaságot vizsgálva, mint említettük, egy - az irodalomban háttérben álló - összefüggést állítunk a középpontba az új jelenséget ismert és új elemek kombinációjaként írjuk le, és elemezzük. Ezáltal visszatérünk a schumpeteri tradícióhoz, amely a vállalkozásokat általában új kombinációk megvalósításaként definiálta, ahogy Dean fogalmaz „Schumpeternél a vállalkozó innovátor, aki a piacon belül újításokat vezet be, új kombinációk kivitelezésével" (Dean, 2016, p. 28.). Vitába szállunk ugyanakkor azokkal a nézetekkel, amelyek a megosztáson alapuló gazdaságot a maga teljességben a profit által vezérelt kapitalista gazdaság alternatívájaként, egyfajta közösségi gazdaságként írják le (Rifkin, 2014; Morgan - Kuch, 2015). Egyszersmind azon felfogásokkal sem értünk egyet, amelyek szerint semmi új nincs az intézményi vállalkozás e típusában, vagyis a megosztást „business as usual”-ként, a kereslet és kínálat csupán technikailag könnyített találkozásaként írják le.

\section{A megosztás (sharing) intézménye}

A megosztást úgy határozhatjuk meg, mint ,az egyének közötti a javak és szolgáltatások elérésére, átadására és megszerzésére irányuló aktivitást, közösségi bázisú online szolgáltatásokon keresztül, vonzó alternatívát kínálva a fogyasztó számára" (Hamari et al., 2016). Tipikus példa erre az Uber és az Airbnb, amellyel cikkünk e részében részletesen foglalkozunk. De a megosztás körébe sorolandók az ún. szívességbankok is. A sharing a legkülönbözőbb területeken terjed a pénzkölcsönzéstôl (ilyen például az Egyesült Királyságban 57.000 taggal múködő Zopa) a használt cikkek egyének közötti kölcsönzésén keresztül (ezt teszi az ausztráliai Open Shed) a szállásközvetítésig (Airbnb).

\section{A megosztás változatai}

A megosztás intézménye tehát tulajdonképpen egy ernyó, amely alatt sokféle változat elfér: a tisztán közösségi alapon múködő, a javaikat másokkal megosztók számára csak a költségeket fedező verzióktól a mobilitást vagy szálláslehetőséget kínálók számára jövedelmet is termelő verziókig.

„A megosztáson alapuló gazdaság a kezdeményezések széles skáláját fogja át a business as usual (BAU)től való marginális eltéréstől a radikális alternatívákig. A megosztáson alapuló gazdaság kezdeményezéseire a fogyasztás oldaláról a kapcsolódó fogyasztás fogalmát használjuk. A megosztáson alapuló gazdaságot a korábbi korok iránti nosztalgia hatja át, amikor az emberek még ismerték a szomszédjaikat, és számíthattak rájuk.
A „kapcsolt” kifejezés e gyakorlatnak mind a digitális, mind a társadalmi aspektusaira utal. Miközben a kínálók oldaláról ez az innováció jövedelemszerzési utak számos változatát nyitja meg, és/vagy növeli a javakhoz vagy a szolgáltatásokhoz való hozzájutást is egyben" (Dubois et al., 2014, p. 51.).

Zavaró lehet, hogy számos - a sharinghez szorosan kapcsolódó - jelenség, illetve fogalom bukkan fel az irodalomban, amelyek definíciójában, illetve kapcsolatuk tisztázásában még messze nincs konszenzus a témával foglalkozók között. Így például találkozhatunk a collaborative consumption, vagy más megfogalmazásban a connected consumption kifejezéssel. Ezt a terminust alkalmazva nem a javait átengedó, hanem a javakat igénybe vevő oldaláról közelítik a sharing jelenséget. Más szerzők ezt az üzleti érdekektől mentes, tiszta megosztás formájaként kezelik, a következőképpen értelmezve a fogalmat: a kapcsolt fogyasztás az, ahol a szereplók megosztják javaikat többnyire a pénz, vagy bármilyen üzleti érdek kikapcsolásával, klasszikus közösségi bázisú megoldást kialakítva (Botsman Rogers, 2011). Magyarországon így múködnek például az ún. szívességbankok, köztük talán a legismertebb a Miutcánk. Használják még a peer to peer economy, pay as you use economy kifejezéseket is, amelyek árnyalatnyilag eltérnek egymástól, az eltéró megnevezés azonban olykor a megosztás különböző változataira utalhat. ${ }^{9}$

Megítélésünk szerint a megosztást célzó intézményi vállalkozások két alapformáját érdemes megkülönböztetni. „Tiszta megosztásnak” nevezziuk azt, amelynél a tranzakcióban részt vevó felek a pénz és a profitérdek kikapcsolásával valósítják meg a javak és szolgáltatások rendelkezésre bocsátását. A másik forma pedig az általunk ,vegyes megosztásnak" nevezett változat, amely a tömegek, a közösség eróforrásaira, potenciáljára támaszkodik, de a javak megosztását fóként az online platformját felkínáló közvetító üzleti érdekei irányítják, és a javakat rendelkezésre bocsátók is szert tesznek jövedelemre a szolgáltatásukból. Ez utóbbi iskolapéldája az Uber és az Airbnb. Cikkünkben kizárólag a vegyes megosztást elemezzük.

Találkozhatunk olyan megközelítéssel is az irodalomban, amely a vegyes, üzleti érdekeket is megjelenító megosztást nem sorolja a sharing körébe. „Ha a sharing a piac által közvetített, vagyis amikor egy társaság a közvetítő olyan fogyasztók között, akik nem ismerik egymást, azt nem tekinthetjük többé megosztásnak. Gazdasági tranzakcióról van szó, amelyben a fogyasztók utilitárius szemléletúek inkább, mintsem társadalmi érdekből cselekszenek... Ez valójában nem sharing economy, hanem access economy" (Eckhardt - Bardh, 2015, p. 2-3.). Itt kell megjegyezni, hogy a két változatot nem mindig könnyú megkülönböztetni. Az Oskar telekocsinál a résztvevők, a javaikat felkínálók nem a 
haszonelvúség jegyében cselekszenek, mivel csupán a benzinköltséget téríttetik meg az igénybe vevővel. A közvetítő pedig igen szerény díjért közvetít. Ez a verzió egyfajta átmenetet képviselhet a két alapforma között.

\section{A megosztáson alapuló vállalkozás: ismert elemek forradalmian új kombinációja}

A megosztáson alapuló gazdaság megjelenésének első időszakában a hangsúly a közösségi jellegen volt, a profittermelő szektor alternatívájának, sôt egy új közösségi gazdaság nyitányának tekintették. Egyes sharing-megoldások ma is közösségi természetúnek minősíthetők . A jellemző azonban - különösen a globális dimenziót öltő megosztáson alapuló szolgáltatások esetében - a profitorientált kapitalista cég koordináló tevékenységének és a közösségi eröforrásoknak a kombinációja.

A javak megosztásának, osztott használatának az intézménye természetesen korábban is létezett, de a szúkebb családi-baráti körre korlátozódott. Nagy lendületet adott a sharingnek, és egyben a jellegét is megváltoztatta az infokommunikációs technológiák berobbanása, ami lehetôvé tette, hogy a tágabb közösséget is megcélozzák. A sharing formát ezért felfoghatjuk a javak megosztása és az internetes közvetítók, azaz a keresletet a kínálattal összekapcsoló e-piacok kombinációjaként is. Nem kell különösebben bizonygatni, hogy a megosztáson alapuló gazdasághoz sorolható mai megoldások nem jöhettek volna létre az internet és a mobiltechnológia nélkül (okostelefon, appok, internetes platformok stb.). Arra már jóval kevésbé gondolunk, hogy a múlt nagy intézményi vállalkozásaiban is gyakran meghatározó szerep jutott az infokommunikációs technológiáknak, természetesen itt a kor színvonalának megfelelő információs technológiákra gondolunk.

Példa erre az 1880-ben bevezetett német társadalombiztosítás, amelyet Bismarck nevéhez kötünk. Ez a nemzeti léptékú intézményi vállalkozás sem jöhetett volna létre azonban az információs technológia korabeli vívmányai nélkül. A társadalombiztosítás ugyanis feltételezi az emberek nyomon követését, adataik rögzítését a rendszerben (írógép, olcsó papír, a német postaszolgálat fejlődése és a professzionális állami bürokrácia) (Shiller, 2005). Ezeket a vívmányokat kombinálták forradalmian új módon a német társadalombiztosítás kialakításával.

A sharing economy mai változatai technológiai értelemben is kombinációkként definiálhatók: egy fizikai jószág (autó, szoba, szerszámok stb.) és az ICT egyesitéseként. Az egyik értelmezhetetlen a másik nélkül. Olyan új kombinációról van szó, amelynek minden eleme ismert, csupán újszerü összekapcsolásuk értékelhetô forradalmi innovációként. Ezzel nem lógnak ki az innovációk sorából, hiszen a legtöbb technológiai, szervezeti és más innováció is ismert elemek összekapcsolásaként szïletett meg.

Klasszikus példa erre a könyvnyomtatás. „Johannes Gutenberg a mozgatható betúket hasznosító nyomtatás feltalálója, két, korábban össze nem kapcsolt tárgyat kombinált: a szőlőprést és a pénzverő szerszámot, hogy egy példátlan invenciót kreáljon, az emberek milliói számára elérhetó nyomtatott könyvet" (Noble Topf, 2014, p. 85.). Maga Gutenberg is forradalmi találmányát a szőlőprés és a pénzverôszerszám kombinációjának tartotta.

A megosztás azon tulajdonsága révén is jól illeszkedik a korszakos trendekbe, hogy a tranzakciók az intézményi vállakozás e formája esetében a materiális javak helyett a funkciókra irányulnak. A megosztást sikerre vívő intézményi vállalkozók arra építettek, hogy az embereknek nem fúrógépre, azaz nem materiális jószágra, hanem a kifúrt lyukra van szükségüik, nem autóra, hanem mobilitásra, nem nyaralóra, hanem szállásra. A dematerializáció jelensége a megosztástól függetlenül is áthatja a XXI. századi gazdaságot. Az emberi szükségletek struktúrájában egyre inkább visszaszorulnak a kézzelfogható termékek, és egyre nagyobb súlyt képviselnek az immateriális jószágok. A Nobel-díjas gazdaságtörténész, Fogel, egy emblematikus cikkében már 1995-re vonatkoztatva úgy becsülte, hogy míg a materiális jellegú fogyasztás (lakás, élelmiszer, ruházkodás) mindössze 12 százalékot képvisel az ún. a kiterjesztett fogyasztásban ${ }^{10}$, addig a tág értelemben vett szabadidős tevékenységek (Leisure) 67 \%-ot (Fogel, 1999, p. 7.). A funkciókat kínáló, megosztáson alapuló vállalkozások ma a dematerializálódó tudásgazdaságba ágyazódnak. Az anyagi termelésben múködő szereplők azonban természetesen továbbra is autót akarnak eladni, és nem mobilitást, továbbra is mesterségesen beépítik az elavulást a háztartási gépekbe, hogy tízévenként ki kelljen őket cserélni, és újból eladhassák a termékeiket ugyanazoknak a fogyasztóknak. Ezért támadt rés az intézményi vállalkozók számára, akik nem javakat, hanem innovatív szolgáltatásokat, a javak funkcióit kínálják a fogyasztóknak, kombinálva a materiális hátteret a funkciók eladásában megnyilvánuló dematerializációval.

A megosztás XXI. századi formái az információs technológiáknak köszönhetően nem csupán ökonomikus szolgáltatásokat tettek lehetôvé, hanem kényelmes, testre szabott szolgáltatásokat is. A testre szabás intézménye a XX. század utolsó évtizedei óta korszakos trend, amely a megosztástól függetlenül átformálja a kínálatot, a tömegtermékek helyett az egyéni igényekhez igazítva azt (Szabó - Kocsis, 2002). A megosztás ebben az értelemben is kombináció, tömeges testreszabásról, vagyis a tömegek számára felkínált szolgáltatás és a speciális egyéni igények kielégitésének a kombinálá- 
sáról van szó. A tömeg szinte a Föld összes lakóját is jelentheti elvben. A 192 országban múködő Airbnb esetében például, amely - mint az a következő pontból is kitúnik - egészen extrém egyéni igények kielégítését is vállalja, gyakorlatilag ez a helyzet.

A tipikus megosztási szolgáltatások nemcsak a felkínált lakások vagy kocsik sokfélesége révén igazodik a fogyasztók speciális igényeihez, hanem az időbeli rendelkezésre állásban is, például az Uber esetében. Miközben a hagyományos taxik kínálata a szolgáltatók számára kényelmetlen időszakokban (például az éjjeli órákban) a valós kereslet alatt van, és így egyes megrendelôk hoppon maradnak, addig az Uber piacán sokkal nagyobb a kínálat ezekben az időszakokban is, köszönhetően a tarifáknak, amelyek éjjel értelemszerúen magasabbak. A rugalmasság nemcsak a fogyasztókhoz való igazodásban, hanem a kocsijukat felkínáló Uber-sofőrök egyéni időbeosztásához való alkalmazkodásban is megnyilvánul, tehát kétoldalúan flexibilis szolgáltatásról kell beszélnünk. Az 1. táblázat a megosztást mint kombinációt mutatja be, összefoglalva az előző fejtegetéseket.

\section{Az intézményi vállalkozás (sharing) mint kombináció}

\begin{tabular}{|l|l|}
\hline \multicolumn{1}{|c|}{$\begin{array}{c}\text { A kombináció } \\
\text { típusa }\end{array}$} & \multicolumn{1}{|c|}{ Példa az adott típusra } \\
\hline $\begin{array}{l}\text { Különbözó ismert } \\
\text { technológiák } \\
\text { kombinációjára épül }\end{array}$ & $\begin{array}{l}\text { Mobil alkalmazás és a modern } \\
\text { internetes platform, valamint } \\
\text { a gépkocsi, illetve a szállás } \\
\text { technológiai kombinációja }\end{array}$ \\
\hline $\begin{array}{l}\text { Az új és a kiszorítani } \\
\text { kívánt hagyományos } \\
\text { szereplôk } \\
\text { kombinációja }\end{array}$ & $\begin{array}{l}\text { Az eróforrásait, javait megosztó } \\
\text { tömeg (közösség) és a (többnyire) } \\
\text { profitorientált közvetító cég } \\
\text { kombinációja }\end{array}$ \\
\hline $\begin{array}{l}\text { Több, másutt már } \\
\text { ismert intézmény } \\
\text { kombinációja }\end{array}$ & $\begin{array}{l}\text { Tömeges testre szabás, funkciók } \\
\text { vásárlása javak helyett, } \\
\text { elektronikus bolhapiac }\end{array}$ \\
\hline $\begin{array}{l}\text { A rugalmas } \\
\text { foglalkoztatás és } \\
\text { a kínálati stabilitás } \\
\text { kombinációja }\end{array}$ & $\begin{array}{l}\text { A rugalmas, fragmentált } \\
\text { egyéni munkakínálat és a stabil } \\
\text { és biztonságos szolgáltatás } \\
\text { kombinációja }\end{array}$ \\
\hline
\end{tabular}

Forrás: saját összeállítás

\section{A megosztás mint intézményi vállalkozás externális hatásai}

Cikkünk elsô részében röviden bemutattuk az intézményi vállalkozásokra általában jellemző sajátosságokat, amelyek révén e vállalkozások jelentős hatást gyakorolnak a legtágabb értelemben vett társadalmi-gazdasági környezetükre. A következőkben azt vizsgáljuk, hogy miként jelentkeznek ezen extern hatások a megosztás esetében.

\section{Az eröforrások mozgósítása: egyenlốtlenségmérséklő és jólétnövelö hatás}

A megosztásra épített intézményi vállalkozásra is jellemzố az intézményi vállalkozások azon általános vonása, hogy kiterjeszti a tranzakciók térbeli és idóbeli határait. Az Airbnb például hatvanmillió felhasználóval dicsekedhet. 640 ezer host tartozik a hálózatához, a portál jellemzője még 2.000.000 listing. 57.000 városban, 192 országban és naponta átlagosan ötszázezren veszik igénybe (2016 első félévéből származó adatok). ${ }^{11}$ Az Uber vonatkozó adatai: nyolcmillió felhasználó, 160 ezer szolgáltató sofőr. Eddig összesen kétmilliárd utat teljesítettek, a napi átlagos igénybevétel egymillió út. Az Uber 400 városban és 70 országban múködik. ${ }^{12}$ Ezeknek a dimenzióknak még a legnagyobb taxivállalatok vagy nemzetközi szállodaláncok sem jöhetnek a közelébe.

Mint már utaltunk rá, a megosztás intézménye olyan tranzakciók tömegét teszi lehetővé, amelyek a hagyományos intézményi keretek között sohasem valósulhattak volna meg.

Tipikus példa erre az Oskar nevû́ hazai autómegosztó egyik igénybe vevőjétól származó komment, amelyet pár hónapja az Oskar oldalán olvashattunk. A vidéken éló nagymama korábban az utazási költségek miatt csak havonta egyszer láthatta az unokáját, az Oskar telekocsi-szolgáltatásnak köszönhetően most ezt sokkal gyakrabban, hetente teheti meg.

A sharing főként olyan javak megosztását, illetve olyan jellegú szolgáltatásokat céloz meg, amelyek az átlagos fogyasztó számára túlságosan drágák. Példával szolgálhat erre a Magyarországról kiszorított Uber vagy az Airbnb. A gépkocsira alapozott mobilitást nem mindenki engedheti meg magának, csakúgy, mint a drága szállodák igénybevételét szabadsága idején. A megosztáson alapuló említett intézményi vállalkozások azonban ezeknek az embereknek a számára is lehetôségeket nyitnak. A megosztás jólétnövelő hatását ezért nehéz túlbecsülni. A relatíve olcsó megosztásos szolgáltatások megkönnyítik az alacsonyabb jövedelmi kategóriákba tartozók, illetve a nehezebb helyzetú csoportok életét, ezáltal mérséklik az egyenlótlenségeket a fogyasztásban. Az 1. ábrán az egyes demográfiai kategóriák súlya látható a szolgáltatást igénybe vevők (feketével jelzett), illetve az igénybe nem vevők (szürkével jelzett) csoportján belül. A feketével jelzett oszlopban az igénybe vevők nem az igénybe nem vevőkhöz vannak viszonyítva, hanem a többi demográfiai kategóriához, azaz például a második oszlopban a nők a férfiakhoz. Mivel két, egymástól jól elkülöníthető csoporton (igénybe vevők, igénybe nem vevők) belül vizsgáljuk 
az egyes demográfiai kategóriák súlyát, nem pedig egy csoporton belül, a szürkével és a feketével jelzett oszlopok adatai nem összegezhetôk. Az 1. ábrából kitúnik, hogy a gyermekes háztartások nagyobb arányban szerepelnek a megosztást igénybe vevők között $(36 \%$,) mint az azon kívül maradók csoportján belül (25\%).

\section{A megosztáson alapuló gazdaság igénybe vevői}

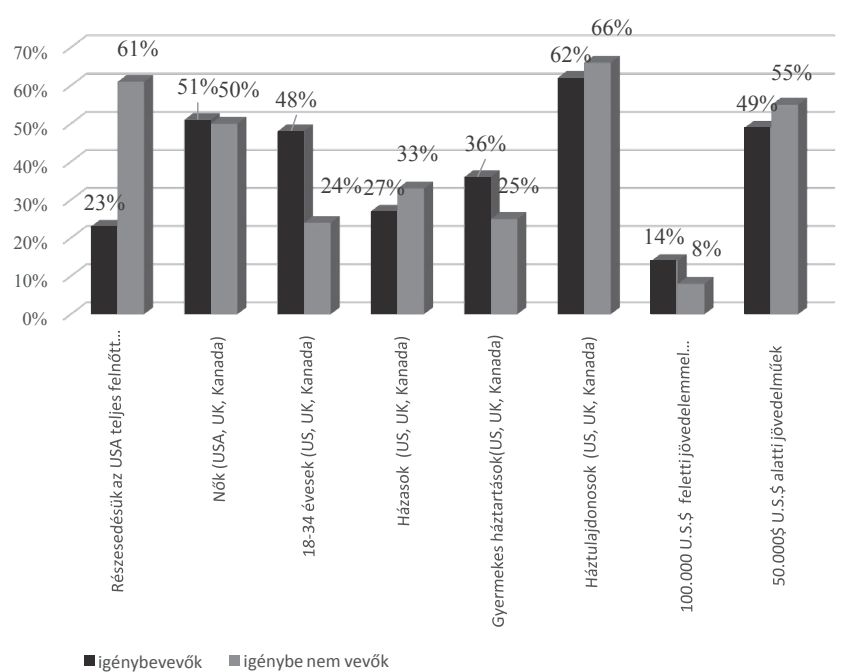

Forrás: The Collaborative Economy: Demographics of "Sharers. www. marketingcharts.com/online/the-collaborative-economy-demographics-of-sharers-41179/

Megjegyzés: A felmérés 2014-ben történt, és az USA-t, Kanadát és az Egyesült Királyságot célozta meg. A megosztást igénybe vevőkhöz azokat sorolták, akik a felmérést megelőző 12 hónapban a megosztás bármilyen formáját igénybe vették.

$\mathrm{Az}$ életkor is erôsen befolyásolja a megosztásos szolgáltatások igénybevételét. Míg az igénybe vevőkön belül 48\% a 18-34 éves, addig azok között, akik ilyen szolgáltatást nem vesznek igénybe mindössze $24 \%$ tartozik ebbe a korcsoportba, a maradék $76 \%$ pedig a többi korcsoportba. Bár a fiatalok esetében valószínúleg nemcsak a szerényebb jövedelmi helyzet a motiváló tényezó a megosztásos szolgáltatások igénybevételében, hanem talán még erősebben a fiatal generáció nagyobb affinitása a digitális világhoz, illetve általában az innovációkhoz.

A fiatalok azonban nemcsak a megosztásos szolgáltatások igénybevételében képviseltetik magukat nagy súllyal, hanem a szolgáltatások kínálatában is jelentôs az arányuk. A 2. ábrán leolvasható, hogy míg a 65 év+ korosztály súlya mindössze 1-2 százalék a megosztásos keretek között dolgozók összességéhez viszonyítva, a 18-24 éves korosztály aránya ezzel szemben 39\%, miközben a fiatal korosztály az USA teljes munkaerô-állományában mindössze $12 \%$-ot képvisel.
2. ábra

A különböző korosztályok aránya az USA teljes munkaeróóállományában, illetve a sharing keretek között dolgozóknál

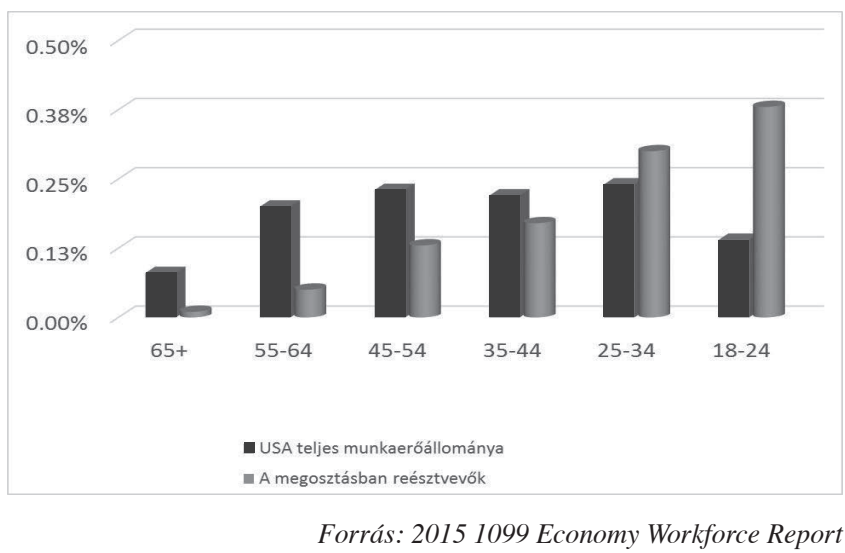

Olyan időszakban, amikor szinte minden országban legnagyobb arányban a fiatalok a munkanélküliség kárvallottjai, a megosztásos intézményi vállalkozásoknak köszönhető új munkalehetőségek jelentőségét is nehéz lenne lebecsülni.

\section{A környezeti hatások}

Az egyéni fogyasztók által megvásárolt, kihasználatlan javak elóállításhoz elképesztô mennyiségú anyagot és energiát, azaz természeti eróforrásokat használnak fel, amelyek környezetterhelése több mint aggasztó. A megosztás - például, ha nem két autóval utaznak az emberek, hanem megosztják az egyikük kocsiját - nyilvánvalóan csökkenti a környezetterhelést. Az Oskar nevú magyar telekocsi-szolgáltatás folyamatosan feltünteti a honlapján a szolgáltatása révén megtakarított $\mathrm{CO} 2$ kibocsátást, amely 2016 . augusztus 10 -én $807.179 .167 \mathrm{~kg}$. A sharing economy emblematikus szereplői: az Uber vagy az Airbnb is ezt teszik. (3. ábra)

3. ábra

Az Airbnb és a fenntarthatóság

Az Airbnb becslése a fenntarthatóság érdekében tett erőfeszítései eredményeiről

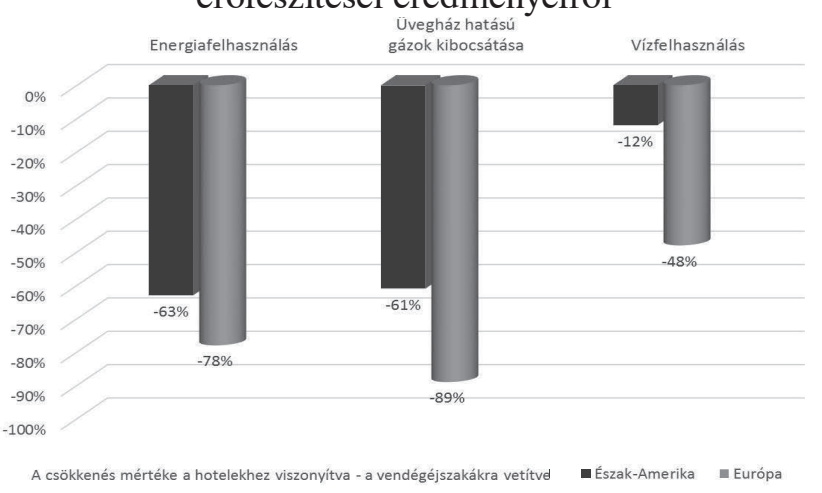

Forrás: http://blog.airbnb.com/environmental-impacts-of-home-sharing/ 
Ugyanakkor a 3. ábrából érzékelhetővel ellentétes hatás is érvényesül. Minthogy olcsóságának köszönhetôen a megosztáson alapuló szolgáltatásokat jóval többen vehetik igénybe, mint hagyományos megfelelóiket, ez elvben nagyobb környezetterhelést is jelenthet, legyen szó akár a személyszállításról, akár üdülésről. $\mathrm{Az}$ Uber például növeli a városi dugók előfordulását az érintett városokban annak összes környezeti következményével együtt. Egyértelmúen „zöld” sharing megoldás ellenben a használt ruhák cseréje, vagy a szerszámok megosztása és a biciklimegosztó portálok tevékenysége.

\section{A megosztás korszakos társadalmi hatása}

Míg a fenti kézzelfogható hatásokat nehéz vitatni, annál vehemensebb vitáknak lehetünk tanúi a megosztás korszakos hatásairól. Korábban említettük már, hogy egyes szerzők egy új, közösségi társadalom nyitányának tekintik a megosztást. Jeremy Rifkin (2014) például - a megosztásos gazdaságot analizálva - egy „piacon túli” világot vizionál, amelyet egy egyre szorosabban összekapcsolódó globális együttmúködő közösségben élünk meg. Morgan és Kuch szerint „A sharing economy fogalmának, ahogyan maga a kifejezés sugallja, olyan konnotációja van, amely inkább gondoskodó és termelō, mint kizsaroló, ahogyan az Janellae Orsi úttörő könyvének alcímében tükröződik: Segíti az embereket szövetkezeteket, szociális vállalkozásokat és lokális fenntartható gazdaságot építeni” (Morgan - Kuch, 2015, p. 557.).

Az előzőkből bizonyára már kitûnt, hogy nem értünk egyet a hasonló megközelítésekkel, nem azonosítjuk a megosztást a közösségépítéssel, amely utóbbi legfeljebb csak a megosztás egy körére jellemző. Az Uber vagy az Airbnb típusú vállalkozásokat egyértelmúen a közösségi megoldások és a profit vezérelt piaci vállalkozás kombinációjaként értelmezzük. Megítélésünk szerint ugyanakkor korai lenne még végleges ítéletet mondani a megosztás mai formáiról, és nemcsak sokrétúségük miatt volna ez megalapozatlan. Akárcsak a korszakos technológiai újításoknál, a megosztáson alapuló gazdaság esetében sem igen tudják a kortársak megítélni, hogy mi lesz a végsố kifutása a születőben lévố trendeknek. Gutenberg és kortársai sem gondolták, hogy a könyvnyomtatás megváltoztatja a világot. Utólag már nem nehéz belátni, hogy Gutenberg nélkül valóban nem lett volna elképzelhetó a kapitalizmus fejlődése. „A kódexekbe aprólékos múgonddal betúket rajzoló szerzetesek munkatempója ugyanis nemigen lett volna alkalmas sem a kötegnyi technológiai leírás kiadására, sem a tömeges szakmai képzés tananyag-ellátására, sem újságok piacra dobására. Ez utóbbiak hiányában pedig aligha képzelhetők el a modern ipari társadalom politikai keretei. A széles (és már írástudó) tömegeket elérő röpiratok, sajtótermékek nélkül sohasem győzedelmeskedhetett volna az ipari tőke a föl- desurak statikus világa felett" (Szabó - Hámori, 2006, p. 46.). A megosztáson alapuló intézményi vállalkozások társadalomra gyakorolt hatása nem vitatható, annál kevésbé lehet azonban a mai tények alapján eldönteni, hogy milyen mértékig formálhatja át a ma uralkodó piacgazdaságokat.

\section{A megosztás és a konvencionális piaci alternatívái}

A megosztáson alapuló gazdaság - mint számos új intézmény - diszruptív jelleget is ölthet, azaz kiszoríthatja az alternatíváját jelentő hagyományos intézményi keretben szervezett szolgáltatásokat.

Mint az eddigiekből is kitúnt, a sharinget útjára indító intézményi vállalkozók reflektálnak az új technológiákra, kihasználják előnyeiket, felülnek az új technológiai hullámra, amely ez esetben az IC-technológiákat jelenti. Az is megkönnyíti az intézményi vállalkozások expanzióját, hogy a konvencionális piaci szereplők gyakran elmennek ezek mellett a lehetóségek mellett, késôn érzékelik a veszélyes versenytársak felbukkanását, és csak akkor ébrednek fel, amikor az új intézmény már kezdi kiszorítani óket. Tipikusan ezt láthattuk például a konglomerátumok vagy az Uber esetében. Azonban - akárcsak az angol landlordok, akikből kapitalisták lettek az ipari forradalom sodrásában - a hagyományos szolgáltatók is átmenthetnék magukat az új keretek közé. Erre azonban csak kevés példát látunk. A világ számos országában, ahol az Uber vagy az Airbnb megjelent, a hagyományos versenytársak inkább állami segítséggel igyekeztek a múködésüket ellehetetleníteni.

Mint az előző fejezet elején közölt adatokból kiolvasható a megosztás további előnye a hagyományos megfelelőihez képest, hogy szinte korlátlan nagyságú rendszerként épülhet ki, hiszen nagy tömeget vonhatnak be a javaikat megosztó szereplők hálózatába. Így olyan szétszórt erőforrások sokaságát mozgósithatják és bocsáthatják a fogyasztók rendelkezésére, amelyek egyébként parlagon hevernének. A fejlett kapitalista gazdaságokban, de sokszor még a fejletlenekben is elképesztô pazarlás folyik a fogyasztás javaival. Sokkoló példa: 80 millió amerikai háztatásban van nagyteljesítményú fúrógép, amelyet egész életciklusuk alatt átlagosan és összesen13 percig (!) használnak. ${ }^{13}$

További elónye a megosztásnak a hagyományos szolgáltatókhoz (például a taxivállalatokhoz vagy a szállodaláncokhoz) képest, hogy míg azok általában csak néhány, legfeljebb néhány tucat különféle verziót kínálnak fel a szolgáltatásukból, addig a megosztási alapon múködő szolgáltatásoknak nemcsak a hálózata kiterjesztett, hanem ebből következően a szolgáltatások választéka is jóval nagyobb. Friedman a következő tényekkel támasztja alá ezt a megállapítást Brian Ches$k y$-t, az Airbnb társalapítóját idézve: 
„Kastéllyal több, mint 600-zal rendelkezünk... Jurták tucatjai, barlangok, vigvamok TV-vel, víztornyok, mobilotthonok, magánszigetek, üvegházak, világítótornyok, igluk wifi-vel [állnak rendelkezésre]. Van olyan házunk, amelyikben Jim Morrison szokott lakni, vannak fára épített házaink, a fára épített házak százai, amelyek egy négyzetméterre vetítve számunkra a legprofitábilisabbak a weboldalunkon lefoglalható összes szállás közül" (Friedman, 2013). Friedman interjúalanya ehhez még azt is hozzáfüzi, hogy „2011-ben a lichtensteini herceg, II. János-Ádám felajánlotta az egész hercegséget az Airbnb számára bérbeadásra, éjszakánként 70.000 dollárért" (Friedman, 2013).

Már említettük, hogy az intézményi vállalkozók nagyobb rugalmasságukkal, a kliensek igényeihez való gyorsabb és jobb alkalmazkodással is háttérbe szoríthatják az inkumbenseket. A kereslet és a kínálat jobb összehangolása az Uber esetében elsôsorban a dinamikus árazásnak tudható be. Míg a hagyományos taxik általában fix árakat alkalmaznak, addig az Uber a csúcsidőszakokban emeli a díjszabást a kereslettől függó mértékben, s ezzel mérsékli a keresletet. Így valóban csak azok veszik igénybe, akik számára ez annyira fontos, hogy többet is hajlandók fizetni érte. Vagyis a kínálat illeszkedése a kereslet oldalán meglévő preferenciákhoz sokkal jobb az időben.

Az új technológiák gyakran nem illeszkednek a hagyományos intézményi keretekhez, az ezek között a keretek között múködő aktorok azonban az idők során már sok erőforrást használtak fel a régi keretekhez való alkalmazkodásra, amelyek elsüllyedt költségeknek tekinthetók. Nemcsak a természetes konzervativizmus magyarázza a hagyományos múködési módhoz való ragaszkodást, hanem az említett elsüllyedt költségek is. $\mathrm{Az}$ új belépő intézményi vállalkozóknak azonban értelemszerúen nem kell számolniuk ilyen költségekkel. A megosztáson alapuló intézményi vállalkozások versenyelőnyeit a hagyományos szolgáltatásokat kínálók sokszor nem saját szolgáltatásaik megújításával, hanem állami segédlettel történő kiszorításukkal próbálják meg semmissé tenni. Több országban - köztük Magyarországon is - ezt tapasztalhatjuk például az Uber esetében. Nem nehéz belátni, hogy nem ez a járható út a hagyományos szolgáltatók számára, hanem az innovációs versenybe való beszállás. Szerencsére erre is vannak példák. Az Uberrel kapcsolatban ezt a reakciót láthatjuk például két budapesti taxivállalatnál is, amelyek az Uberhez képest ugyan nem újították meg radikálisan a szolgáltatásukat, de - átvéve az okostelefon-alkalmazás elemét - igyekeztek az utasok számára az Uberhez hasonlóvá tenni a szolgáltatásukat (legalábbis ebben a vonatkozásban). A 2. táblázatban foglaljuk össze a megosztáson alapuló szolgáltatások tulajdonságait a hagyományos szolgáltatásokkal összevetve.
2. táblázat

A megosztás és a konvencionális piaci alternatívák

\begin{tabular}{|c|c|c|}
\hline Megnevezés & $\begin{array}{l}\text { Hagyományos } \\
\text { intézmény }\end{array}$ & $\begin{array}{c}\text { Megosztás } \\
\text { (az Uber és az Airbnb } \\
\text { példáján) }\end{array}$ \\
\hline $\begin{array}{l}\text { Az intézmény } \\
\text { jellege }\end{array}$ & Piaci & $\begin{array}{l}\text { Közösségi és piaci } \\
\text { kombinációja }\end{array}$ \\
\hline $\begin{array}{l}\text { Technológiai } \\
\text { háttere }\end{array}$ & $\begin{array}{l}\text { Alapvetően ha- } \\
\text { gyományos }\end{array}$ & $\begin{array}{l}\text { Mobil alkalmazás, } \\
\text { okostelefon, } \\
\text { internetes platform }\end{array}$ \\
\hline $\begin{array}{l}\text { Hatalmi-piaci } \\
\text { pozíciója }\end{array}$ & $\begin{array}{l}\text { Hard power, do- } \\
\text { mináns pozíció, } \\
\text { meghatározó piaci } \\
\text { részesedés (Har- } \\
\text { gadon - Douglas, } \\
\text { 2001) }\end{array}$ & $\begin{array}{l}\text { Soft power, új belépó, } \\
\text { piaci rés (a nagyságból } \\
\text { fakadó közelség a kli- } \\
\text { ensekhez.) Erőforrásaik } \\
\text { messze meghaladják a } \\
\text { legnagyobb hagyomá- } \\
\text { nyos szolgáltatóét is. }\end{array}$ \\
\hline $\begin{array}{l}\text { Tranzakciós } \\
\text { költség }\end{array}$ & Magas & Alacsony \\
\hline $\begin{array}{l}\text { Társadalmi } \\
\text { veszteségek } \\
\text { (meghiúsult } \\
\text { tranzakciók) }\end{array}$ & $\begin{array}{l}\text { Nagy (Dahlman, } \\
\text { 1979) }\end{array}$ & $\begin{array}{l}\text { Jelentősen mérsékli a } \\
\text { veszteségeket }\end{array}$ \\
\hline $\begin{array}{l}\text { Preferencia- } \\
\text { illeszkedés, } \\
\text { rugalmasság }\end{array}$ & $\begin{array}{l}\text { Hézagos, rugal- } \\
\text { matlan, költség”+ } \\
\text { vagy más rögzített } \\
\text { ár }\end{array}$ & $\begin{array}{l}\text { Javított illeszkedés, } \\
\text { dinamikus árazás }\end{array}$ \\
\hline $\begin{array}{l}\text { Növekedési } \\
\text { potenciál (jó- } \\
\text { lét növelése) }\end{array}$ & Nincs, vagy kicsi & $\begin{array}{l}\text { Nagy növekedési } \\
\text { potenciál }\end{array}$ \\
\hline Szabályozás & $\begin{array}{l}\text { Állami (túlszabá- } \\
\text { lyozás) }\end{array}$ & $\begin{array}{l}\text { Reputációalapú } \\
+ \text { állami szabályozás }\end{array}$ \\
\hline
\end{tabular}

Forrás: saját összeállítás

Végül, de nem utolsósorban a sharing economy mögött az önszabályozás igénye és nélkülözhetetlensége is kirajzolódik. Az egyre komplexebb, bonyolult hálózatokban müködó globális gazdaságot egyre nehezebb állami irányítás alá vonni. Az állami bürokrácia lomhasága kiáltó ellentétben van a gazdaság hektikus változásaival. Kiutat ebból csak az önszabályozás kínálhat. A megosztáson alapuló gazdaság alapvetóen önszabályozásra épül, bár ez nyilván nem jelenti és nem is jelentheti az állami szabályozás teljes visszahúzódását. A sharing léte mindazonáltal a túlszabályozásra adott reakcióként is felfogható. Azok az államok járnak el helyesen, amelyek meghagyják az önszabályozás lehetőségét, és csak a szükséges mértékben, az érintettekkel egyeztetve avatkoznak be, hogy kiküszöböljék az új intézmény vadhajtásait, illetve gyermekbetegségeit. (Ilyen jó példával szolgál térségünkben Észtország.) 
A 4. ábrán - cikkünk mondanivalójának egyfajta összegzéseként - bemutatjuk azokat a mai gazdaságban tapasztalható, a hagyományos intézményi kereteket szétfeszító feszültségeket, amelyek feloldására a megosztás intézménye kínál lehetőségeket.

\section{Feszülttségek a fennálló intézményrendszerben}

4. ábra

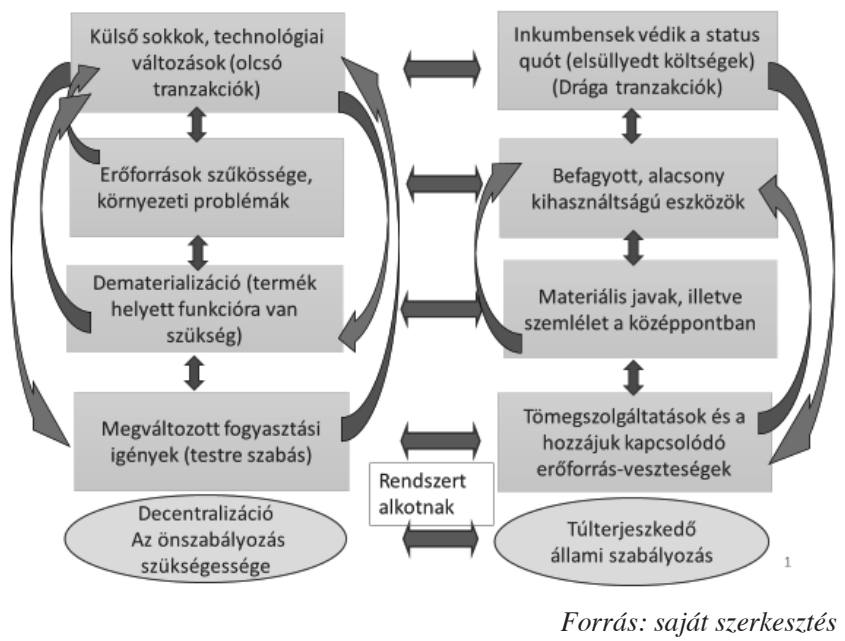

$\mathrm{Az}$ ábra egyes elemeirôl, illetve a köztük lévő kapcsolatokról már sok szó esett cikkünk különböző részeiben. Az ábrával azt kívánjuk jelezni, hogy a feszültségek a XXI. századi kihívások és a konvencionális piaci szereplők jellemzői között nem függetlenek egymástól. Az ábra jobb oldalán szerepeltettuik azokat a konvencionális piaci szereplőkhöz köthető problémákat, tulajdonságokat, amelyek miatt e szereplők nehézkesen reagálnak a XXI. századi kihívásokra. A kihívásokat az ábra bal oldalán tüntettünk fel, ezek szintén rendszert alkotnak, egymással összefüggnek. Az ábrán szereplő nyilak jelzik a kölcsönös összefüggéseket, illetve a vízszintesen elhelyezett nyilak a feszültségeket a hagyományos intézményi keretek között dolgozó szereplók és a mai gazdaság trendjei és kihívásai között.

Természetesen a kihívásokra reagáló az intézményi vállakozókat nemcsak e kihívások és körülmények, hanem belső motivációk is irányítják. „Új intézmények akkor jönnek létre... amikor a (szervezett) aktor(ok) elegendő erőforrással felruházva, lehetôséget látnak arra, hogy a saját kiemelkedően fontos érdekeiket megvalósítsák" (DiMaggio, 1988, p. 14.). A megmerevedett struktúrák között a kreatív kívülállók csak újításokkal tudnak betörni a piacra. Sokszor még ez sem elég, az intézményi kereteket kell szétfeszíteniük.

\section{Összefoglalás, következtetések}

1. Az intézményi vállalkozás - gyorsan gyarapodó irodalma ellenére - számos tisztázatlan kérdést vet fel, tanulmányunkban ezek némelyikére igyekeztünk választ adni, érveket sorakoztatva fel a probléma relevanciája, időszerúsége mellett.

2. Az intézményi vállalkozások tengelyében a fennálló intézmények megváltoztatása áll. Az ezt konceptualizáló ún. agency elmélet kulcsszerepet tulajdonít az emberi aktivitásnak az intézményépítésben.

3. Az intézményi vállalkozásokkal kapcsolatban megfogalmazott, elvont állításokat a megosztáson alapuló gazdaság példáján keresztül kívántuk kézzelfoghatóbbá tenni. Ez a viharosan terjedô új jelenség talán a legfontosabb mai intézményi vállalkozás, amelyet igyekeztünk differenciáltan bemutatni, világosan megkülönbözetve az üzleti érdekektől és profitszempontoktól mentes, ,„tiszta sharinget”, ezen intézményi vállalkozás vegyes verziójától, amely a közösségi erőforrások és az üzleti alapon múködtetett platformok összekapcsolása. Cikkünkben részletesen csak ez utóbbit elemeztük.

4. Választ kerestünk arra a kérdésre is, hogy vajon intézményi vállalkozók által létrehozott, az Uber és az Airbnb által fémjelzett sharing radikálisan új intézmény-e, vagy csupán egyfajta digitalizált piactér, amely csak technikailag könnyíti meg a kereslet és a kínálat találkozását. Cikkünkben azt igyekeztünk igazolni, hogy a megosztáson alapuló gazdaságot létrehozó ágensek nem csupán technikai módosítást, hanem mélyreható tartalmi változásokat hoznak a gazdasági tranzakciókban, a tulajdonhoz való viszonyban és a társadalom egészének a múködésében is. Nem a „kereslet” és a „kínálat” összehozása az új elem a megosztáson alapuló gazdaságban, hiszen a csere már a történelem előtti idókben is létezett. A törzsek közötti cserét azonban nem moshatjuk egybe sem az athéni agorával, sem a mai globális piacokkal, noha mindegyikük leírható a kereslet-kínálat találkozásaként. Ezen túl azonban számos, más tulajdonságukban különböznek, ahogyan a mai konvencionális kapitalista vállalkozásokat és megosztáson alapuló intézményi vállalkozását összevetve bemutattuk.

5. A cikk fó hozzájárulása a területen folyó kutatásokhoz, hogy két új témakört: az intézményi vállalkozást és a megosztáson alapuló gazdaságot összekapcsolva, ez utóbbit több vonatkozásban is ismert elemek kombinációjaként írja le. A vegyes megosztás korábban nem tőkeként múködő kapacitásokat és eróforrásokat hoz mozgásba, és transzformál „kvázi tôkévé". Ezáltal csökkenti a meghiúsult tranzakciókból adódó társadalmi veszteséget, mérsékli a kör- 
nyezetterhelést és a tranzakciós költségeket egyaránt, növeli a gazdaság egészének a rugalmasságát és növekedési potenciálját, gyógyírt kínálva számos égető társadalmi problémára. Nem vitatjuk természetesen, hogy a megosztáson alapuló új intézményi vállalkozás számos problémát is felvet, és sok buktatóját azonosították már az irodalomban, ezek kifejtésére azonban terjedelmi korlátok miatt nincs lehetőségünk.

\section{Jegyzetek}

${ }^{1}$ A szerző köszönetet mond az anonim lektoroknak, továbbá tanszéki kollégáinak és a Makroökonómiai Tanszék munkatársainak akik kritikájukkal érdemlegesen hozzájárultak e kutatási téma továbbfejlesztéséhez.

${ }^{2}$ Lásd erről részletesen Leca et al. (2008).

${ }^{3}$ Nem tévesztendő össze a megbízó-ügynök elmélettel.

${ }^{4}$ A szerzóhármas ezzel összefüggésben DiMaggio és Powell (1983) cikkére és Scott (2008) könyvére hivatkozik.

${ }^{5}$ „Most sokkal szigorúbban definiáljuk az innovációt a termelési függvény eszközével. Ez a függvény leírja azt a módot, ahogyan a termékek mennyisége változik a tényezők mennyiségének a változásával. Ha mi a tényezők mennyiségének a változtatása helyett a termelési fuiggvény formáját változtatjuk meg, akkor beszélünk innovációról. ... Egyszerúen úgy definiáljuk az innovációt, mint egy új termelési függvény felállítását” (Schumpeter, 1939/1964, p. 86.).

${ }^{6}$ A széles körben hódító behavioral economics (Shiller, 2005) irányzat is ezt a trendet igazolja.

${ }^{7}$ Parciális vizsgálatok, kiragadott statisztikai elemzések természetesen léteznek, cikkünkben prezentálunk is néhányat ezek közül. Azok eredményei azonban messze nem általánosíthatók, és némely esetben az is csökkenti az értéküket, hogy olyan adatszolgáltatóktól származnak, akik maguk is érdekeltek a statisztikák által kimutatott eredményekben.

${ }^{8}$ Konvencionális piaci szereplők a profitérdekelt tőkés vállalkozások a KKV-ktől a multinacionális konszernekig, konvencionális megoldásokon értjük az ő szokásos tranzakcióikat, illetve tevékenységüket.

${ }^{9}$ Ezek részletes bemutatása, egyfajta sharing taxonómia felállítása azonban külön cikket igényelne.

${ }^{10} \mathrm{~A}$ kiterjesztett fogyasztás nem csupán az adott jószágra történó pénzbeli ráfordításokat tartalmazza, hanem az összes (pénzbeli + időbeli) ráfordítást, mégpedig oly módon, hogy az egyes fogyasztási jószágcsoportokkal kapcsolatos időráfordítás arányait az emberi szervezet fiziológiai szükségleteire (alvás stb.) fordított idő levonása után megmaradt időalapból származtatja. A különböző fogyasztási típusokra fordított idő (pénzre átszámítva) és fogyasztási javakra és szolgáltatásokra kiadott pénz adja együttesen a kiterjesztett fogyasztást. Ezt veszi Fogel 100 százaléknak, és ennek megoszlását vizsgálja a különböző fogyasztási kategóriák között.

${ }^{11}$ Forrás: http://expandedramblings.com/index.php/airbnb-statistics/

${ }^{12}$ Forrás: http://expandedramblings.com/index.php/uber-statistics/

${ }^{13}$ Forrás: http://www.roughtype.com/?p=6527

\section{Felhasznált irodalom}

Acs, Z. (2006): How Is Entrepreneurship Good for Economic Growth? Innovation, Technology, Governance, and Globalization, 1 (1) Winter, p. 97-107.

Battilana, J. - D'Aunno, T. (2009): Institutional Work and the Paradox of Embedded Agency. in: Lawrence, T. B. - Suddaby, R. - Leca, B. (eds.): Institutional Work: Actors and Agency in Institutional Studies of Organizations. Cambridge, UK: Cambridge University Press
Bockhaven, W. - Matthyssens, P. - Vandenbemt, $K$. (2015): Empowering the Underdog: Soft Power in the Development of Collective Institutional Entrepreneurship in Business Markets. Industrial Marketing Management, 48, p. 174-186.

Botsman, R. - Rogers, R. (2011): What's Mine is Yours - How Collaborative Consumption Is Changing the Way We Live. London: Collins

Christensen, C. (1997/2013): The Innovator's Dilemma. The Innovator's Solution, How Will You Measure Your Life? Boston: Harvard Business Review Press

Dahlman, C. J. (1979): The Problem of Externality. The Journal of Law and Economics, 22 (1), p. 141-162.

Dean, T. J. (2016): New Venture Formations in United States Manufacturing: The Role of Industry Environments. New York: Routledge

Dew, N. (2006): Institutional Entrepreneurship A Coasian Perspective. Entreprenurship and Innovation, February, p. 13-22.

DiMaggio, P. (1988): Interest and Agency in Institutional Theory. in: Zucker, L. (ed.): Institutional Patterns and Organizations. Cambridge (Mass): Ballinger Publishing Company, p. 3-21.

DiMaggio, P. J. - Powell, W. W. (1983): The Iron Cage Revisited: Institutional Isomorphism and Collective Rationality in Organizational Fields. American Sociological Review, 48 (2)., p. 147-160.

Dorado, S. (2005): Institutional Entrepreneurship, Partaking, and Convening. Organization Studies, 26 (3), p. 383-413.

Dubois, E. - Schor, J. - Carfagna, L. (2014): Connected Consumption a Sharing Economy Takes Hold. Dissatisfied with Traditional Market Exchanges, a Growing Number of Consumers Are Developing a New Suite of Non-Monetary Consumption Models. Rotman Management, Spring, University of Toronto, Toronto

Eckhardt, G. M. - Bardh, F. (2015): The Sharing Economy Isn't About Sharing at All. Harvard Business Review, Janauary 28. https://hbr.org/2015/01/thesharing-economy-isnt-about-sharing-at-all

Fogel, R. W. (1999): Catching up with the Economy. American Economic Review, 89 (1), p. 11-22.

Friedman, T. L. (2013): Welcome to the 'Sharing Economy'. New York Times, July 20. http://www. nytimes.com/2013/07/21/opinion/sunday/friedman-welcome-to-the-sharing-economy.html?_r=0

Gleick, J. (1999): Faster: The Acceleration of Just About Everything. London: Little, Brown Book Group

Hamari, J. - Sjöklint, M. - Ukkonen, A. (2016): The Sharing Economy: Why People Participate in Collaborative Consumption. Journal of the Association for Information Science and Technology, 67(9), p. C1-C1, 2045-2306. 
Hardy, C. - Maguire, S. (2008): Institutional Entrepeneurship. in: Greenwood, R. et al. (eds): Handbook of Organizational Institutionalism. London: SAGE Publication, p. 198-217.

Hargadon, A. - Douglas, Y. (2001): When Innovations Meet Institutions: Edison and the Design of the Electric Light. Administrative Science Quarterly, 46 (3), p. 476-501.

Hayek, F. A. (1988): The Fatal Conceit. Chicago: University of Chicago Press

Lawrence, T. - Suddaby, R. (2006): Institutions and Institutional Work. in: Clegg, S. - Hardy, C. - Lawrence, T. - Nord, W. R. (eds.): Handbook of Organization Studies. (2nd ed.). London: Sage Publications, p. 211-254.

Lawrence, T. B. - Suddaby, R. - Leca, B. (2009): Introduction: Theorizing and Studying Institutional Work. in: Lawrence, T. B. - Suddaby, R. - Leca, B. (eds.): Institutional Work: Actors and Agency in Institutional Studies of Organizations. Cambridge, UK: Cambridge University Press, p. 1-27.

Leca, B. - Battilana, J. - Boxenbaum, E. (2008): Agency and Institutions: A Review of Institutional Entrepreneurship. Working Paper

Levy, D. - Scully, M. (2007): The Institutional Entrepreneur as Modern Prince: The Strategic Face of Power in Contested Fields. Organization Studies, 28(7), p. 971-991.

Morgan, B. - Kuch, D. (2015): Radical Transactionalism: Legal Consciousness, Diverse Economies, and the Sharing Economy. Journal of Law and Society, 42 (4), p. 556-587.

Nelson, R. (2005): Technology, Institutions and Economic Growth. Cambridge, MA: Harvard University Press

Noble Topf, L. (2014): Wheelcar Wisdom. iUniverse. (Elektronikus Kiadó)
North, D. (1990): Institutions, Institutional Change and Economic Performance. Cambridge: Cambridge University Press

Raffaely, R. - Glynn, M. A. (2015): Institutional Innovation. Novel, Useful and Legitimate. in: Shalley, C. - Hitt, M. A. - Zhou, J. (eds): The Oxford Handbook of Creativity, Innovation, and Entrepreneurship. Oxford: Oxford University Press, p. 407-420.

Rifkin, J. (2014): The Zero Marginal Cost Society: The Internet of Things, the Collaborative Commons, and the Eclipse of Capitalism. New York: St. Martin's Press

Samuelson, P. A. (1976): Közgazdaságtan. Budapest: Közgazdasági és Jogi Könyvkiadó

Scott, W. R. (2008): Institutions and Organizations. London: SAGE Publications

Shiller, J. (2005): Behavioral Economics and Institutional Innovation. Cowles Foundation for Research in Economics. Yale University. New Haven, Connecticut

Schumpeter, J. A. (1980/1911): A gazdasági fejlődés elmélete. Budapest: Közgazdasági és Jogi Könyvkiadó

Schumpeter, J. A. (1939): Business Cycles: A Theoretical, Historical and Statistical Analysis of the Capitalist Process. New York: McGraw Hill

Szabó Katalin - Kocsis Éva (2002): Digitális paradicsom vagy falanszter? A személyes tömegtermelés. Budapest: Aula Kiadó

Szabó Katalin - Hámori Balázs (2006): Információgazdaság. Digitális kapitalizmus vagy új gazdasági rendszer? Budapest: Akadémiai Kiadó

Williamson, O. E. (1975): Markets and Hierarchies: Analysis and Anti-trust Implication. New York: Free Press

Williamson, O.E. (1985): The Economic Institutions of Capitalism. New York: The Free Press 